\title{
Examining the social media teacher-student interactions of physical education teachers
}

\author{
Çağnı Hamdi ERDOĞAN ${ }^{1}$, Ziya BAHADIR², Ramazan TOPUZ ${ }^{3}$
}

\author{
${ }^{1}$ Çömlekçi Middle School, Ministry of Education, Kayseri, Turkey \\ ${ }^{2}$ Erciyes University, Faculty of Sport Sciences, Kayseri, Turkey \\ ${ }^{3}$ Selçuk University, Faculty of Sport Sciences, Konya, Turkey \\ Address Correspondence to ÇH. ERDOĞAN e-mail: erdoganhamdi@hotmail.com
}

\begin{abstract}
This study was The aim of this research is to examine the interactions between the physical education teachers and students in social media based on some variables. In the study, a descriptive survey method was used, which aimed at revealing the existing situation. There search group was comprised of 390physicaleducationteachersactivelyworking at the state schools of Kayseri province in the 2018-2019educationyear.Personal Information Form and Social Media Teacher - Student Interaction Scale were used in the study as the data collection tools. SPSS program was used in the analysis of the data. According to results of the research, it was determined that the social media teacher-student interaction levels of the physical education teachers were at the medium range. In addition, it was determined that virtual leader characteristics of physical education teachers were prominent. Also a significant difference was found concerning the social media teacher-student interaction levels of the physical education teachers for the variables school location, sport branch, physical education infrastructure in the school, the school team status, regular exercise, age, monthly income perception; however, statistically no significant difference was determined concerning the variables school type, marital status, and gender.
\end{abstract}

Keywords: Physical Education Teacher, Student, Social Media

\section{INTRODUCTION}

Human being has been under the influence of technological developments in the 21st century. Information technologies have appeared in every division of life. Hi-tech televisions, computers, and mobile devices have been indispensable for the daily life. Our age is named as the internet age. World has witnessed numerous innovations through internet. One of those innovations is the social media.

Social media is a combination of social network sites supported by activities such as content sharing and personal comments that allow internet users to communicate online with each other in an interactive way (18). Based on the experiences of people with each other on the social networks, social media is the sum of the relationships that keep together the users with same fields of interest (11).

Social media is one of the technological innovations that allow the creation, sharing and exchange of information and ideas in virtual communities and networks. Social media ensures a social interaction among people by allowing the sharing of ideas and information with other people (27). Social media is a web-based interface that allows its users to create profiles, and communicate and contact about certain issues (17).

Social networks provide its users with rich contents and interactions with other users. This situation can be clearly observed in the interaction 
pattern of social media users. Social networks are not comprised of only family members or friends,additionally there are teachers, school personnel, neighbors, who are a part of our daily life, and other individuals finding a place in the social network (7).

Social media is widely used among the students as well. Majority of the students using social media use it as a means of entertainment and relief, and they spend an important amount of time like three hours daily average in social media (20).Moreover, it is reported that the students use the social media for sharing photos, music, video, and contents related with lessons, for being in contact concerning the lessons, and for being involved in interaction with other friends during this mentioned daily time periods in the social media (23).

The basic aim of using the social media is the involvement of the users in social interactions (22). Interaction is the most basic element of any educational process (2). With the use of social media being widespread, it is also stated that the teacherstudent interaction in the school is spread to the areas outside the school (9).

It is mentioned that the use of social network platforms by students for education will provide important gains (24). It is reported that use of social media in education is necessary (14). It is emphasized that the social media platforms develop the communication between teachers and students (1).

The main aim of this research study is to investigate the social media teacher-student interactions of the physical education teachers. Moreover, the social media teacher-student interaction levels of physical education teachers were compared in terms of some variables.

\section{MATERIAL AND METHOD}

\section{Research Model}

The research was conducted as a survey model for examining the social media teacher-student interactions of physical education teachers. Survey model is a research approach that attempts to identify a situation as it was in the past or as is in the present (15).

\section{Research Group}

The research group is consisted of a total of 390 physical education teachers, who work in the public schools within the provincial borders of Kayseri in the 2018-2019 academic year. $81(20.8 \%)$ of the physical education teachers from the research group were female and 309 (79.2\%) were male.

\section{Data Collection Tools}

In the research, "Personal Information Form" and "Social Media Teacher-Student Interaction Scale" were used as data collection tools. The Personal Information Form was prepared by the researchers, taking into account the expert opinion and similar research in the literature. The Social Media Teacher-Student Interaction Scale was developed by Korucu and Usta (19).

The Social Media Teacher-Student Interaction Scale is a five point likert scale consisting of 34 items and six sub-dimensions. The average scores were calculated through the scores ranging from 1 to 5 (minimum score to gain from the scale in this research study is 1 and maximum is 5), and the findings were obtained in this way. Higher scores obtained from the scale indicate higher level of social media teacher-student interaction.In their analyses, Korucu and Usta (19) the cronbach alpha reliability coefficients of the scale according to the factors in between .74 and .84, and test-retest reliability coefficients in between .87 and .88 .

\section{Data Analysis}

The SPSS program was used for statistical analysis in this research. In order to examine the social media teacher-student interactions of physical education teachers, the arithmetic average ( ) and standard deviation ( $\mathrm{Sd}$ ) techniques were used, which are the elements of the descriptive statistics. In the analyses, it was investigated through Kolmogorov-Smirnov Test whether the data followed a normal distribution. As a result, it was found that social media teacher-student interaction scores did not follow a normal distribution $(p=.000)$. Since social media teacher-student interaction scores did not follow a normal distribution, the MannWhitney U Test was employed for paired comparisons, and Kruskal Wallis H Test for multiple comparisons. Significance (p) level was accepted as $\mathrm{p}<0.05$. 


\section{FINDINGS}

Table 1. The distribution of some of the characteristics of the physical education teachers from the research group

\begin{tabular}{lcc}
\hline Gender & $\mathbf{n}$ & $\mathbf{\%}$ \\
\hline Female & 81 & 20.8 \\
Male & 309 & 79.2 \\
\hline Age & $\mathbf{n}$ & $\mathbf{\%}$ \\
\hline 20-29 Years Old & 159 & 40.8 \\
30-39 Years Old & 159 & 40.8 \\
40 and Over & 72 & 18.4 \\
\hline Marital Status & $\mathbf{n}$ & $\mathbf{\%}$ \\
\hline Married & 333 & 85.4 \\
Single & 57 & 14.6 \\
\hline Location of the School & $\mathbf{n}$ & $\mathbf{\%}$ \\
\hline Rural & 132 & 33.8 \\
Urban & 258 & 66.2 \\
\hline Monthly Income Perception & $\mathbf{n}$ & $\mathbf{\%}$ \\
\hline Low & 84 & 21.5 \\
Medium & 261 & 66.9 \\
High & 45 & 11.6 \\
\hline
\end{tabular}

\begin{tabular}{|c|c|c|}
\hline $\begin{array}{l}\text { Physical Education Infrastructure } \\
\text { in the School }\end{array}$ & $\mathbf{n}$ & $\%$ \\
\hline Sufficient & 159 & 40.8 \\
\hline Insufficient & 231 & 59.2 \\
\hline Sport Branch & $\mathbf{n}$ & $\%$ \\
\hline Individual Sport & 141 & 36.2 \\
\hline Team Sport & 249 & 63.8 \\
\hline Doing Regular Exercise? & $\mathbf{n}$ & $\%$ \\
\hline Yes & 189 & 48.5 \\
\hline No & 201 & 51.5 \\
\hline Training A School Team? & $\mathbf{n}$ & $\%$ \\
\hline Yes & 219 & 56.2 \\
\hline No & 171 & 43.8 \\
\hline School Type & $\mathbf{n}$ & $\%$ \\
\hline Secondary School & 168 & 43.1 \\
\hline High School & 222 & 56.9 \\
\hline
\end{tabular}

Among the physical education teachers from the research group; 81 (20.8\%) were female and 309 (79.2 \%) were male; 159 (40.8\%) were 20-29 years old, $159(40.8 \%) 30-39$ years old, and $72(18.4 \%)$ of them were 40 and over; 333 of them $(85.4 \%)$ were married and $57(14.6 \%)$ were single; the school locations of $132(33.8 \%)$ were rural, while those of $258(66.2 \%)$ were urban; the physical education infrastructures of 159 teachers $(40.8 \%)$ were sufficient, while those of $231 \quad(59.2 \%)$ were insufficient; 141 (36.2\%) had individual sport branches, while 249 teachers (63.8\%) had team sport branches; 189 (48.5\%) were doing regular exercises, while $201(51.5 \%)$ were not; 219 of them $(56.2 \%)$ trained a school team, whereas $171(43.8 \%)$ did not; 84 teachers $(21.5 \%)$ had a low income perception, while $261(66.9 \%)$ at medium level, and 45 (11.6\%) had a high level income perception; 168 (43.1\%) were working in secondary schools, and 222 (56.9\%) in high schools.

\begin{tabular}{|c|c|c|c|}
\hline $\begin{array}{l}\text { Sub-dimensions of Social Media } \\
\text { Teacher - Student Interaction Scale }\end{array}$ & $\mathbf{n}$ & $\bar{X}$ & Sd \\
\hline Virtual Leader & 390 & 3.64 & .787 \\
\hline Traditional Teacher & 390 & 2.93 & 1.066 \\
\hline Observing Teacher & 390 & 3.16 & 1.094 \\
\hline Virtual Activeness & 390 & 3.10 & 1.128 \\
\hline Social Sharing & 390 & 3.46 & 1.253 \\
\hline Academic Sharing & 390 & 3.42 & 1.258 \\
\hline Total & 390 & 3.34 & .785 \\
\hline
\end{tabular}

As is seen in Table 2, it is observed that the physical education teachers obtained following average scores from the sub-dimensions of Social Media Teacher-Student Interaction Scale; Virtual
Leader $\quad \bar{X}=3.64, \quad$ Traditional Teacher $\quad \bar{X}=2.93$, Observing Teacher $\bar{X}=3.16$, Virtual Activeness $\bar{X}$ $=3.10$, Social Sharing $\bar{X}=3.46$, and Academic 
Sharing $\bar{X}=3.42$. According to these results, it was determined that the physical education teachers from the research group obtained the highest score from the "virtual leader" sub-dimension. It was also determined that the physical education teachers from the research group obtained an average score of $\bar{X}=3.34$ in general, from the Social Media Teacher-Student Interaction Scale. Accordingly, it can be mentioned that the social media teacherstudent interactions of the physical education teachers are at a "medium range".

Table 3. Comparison of the social media teacher-student interaction levels of the physical education teachers concerning gender, marital status, school type, and school location

\begin{tabular}{clcccccc}
\hline & & $\mathbf{n}$ & $\overline{\mathrm{X}}$ & $\mathbf{S d}$ & $\mathbf{U}$ & $\mathbf{p}$ & Difference \\
\hline \multirow{2}{*}{ Gender } & Female & 81 & 3.16 & .672 & 1163.000 & .192 & No \\
& Male & 309 & 3.38 & .808 & & & \\
\hline \multirow{2}{*}{ Marital Status } & Married & 333 & 3.39 & .799 & 826.000 & .132 & No \\
& Single & 57 & 3.04 & .636 & & & \\
\hline \multirow{2}{*}{ School Type } & Secondary School & 168 & 3.45 & .871 & 1889.000 & .389 & No \\
& High School & 222 & 3.26 & .707 & & & \\
\hline School Location & Rural & 132 & 3.99 & .735 & 607.500 & $.000^{*}$ & Yes \\
& Urban & 258 & 3.00 & .571 & & &
\end{tabular}

${ }^{*} \mathrm{p}<0.05$

As is seen on Table 3, the social media teacher-student interaction levels of the physical education teachers from the research group did not demonstrate any statistically significant difference concerning gender, marital status, and school type; however, a statistically significant difference was determined concerning the location of the school.

The social media teacher-student interaction levels of the physical education teachers working in the rural areas determined to be higher compared to those of the physical education teachers working in urban areas.

Table 4. Comparison of the social media teacher-student interaction levels of the physical education teachers from the research group concerning sport branch, lesson infrastructure, school team, and doing regular sport

\begin{tabular}{|c|c|c|c|c|c|c|c|}
\hline & & $\mathbf{n}$ & $\overline{\mathrm{X}}$ & Sd & $\mathbf{U}$ & $\mathbf{p}$ & Difference \\
\hline Sport Branch & Individual Sport & 141 & 3.10 & .722 & 1438.500 & $.013^{*}$ & Yes \\
\hline \multirow[t]{2}{*}{ Lesson Infrastructure } & Sufficient & 159 & 3.58 & .754 & 1456.500 & $.006^{*}$ & Yes \\
\hline & Insufficient & 231 & 3.17 & .768 & & & \\
\hline School Team & No & 171 & 3.12 & .784 & & & \\
\hline \multirow[t]{2}{*}{ Regular Exercise } & Yes & 189 & 3.49 & .795 & 1682.500 & $.046^{*}$ & Yes \\
\hline & No & 201 & 3.19 & .752 & & & \\
\hline
\end{tabular}

${ }^{*} \mathrm{p}<0.05$

As is seen in Table 4, the social media teacher-student interaction levels of the physical regularly did exercise, had higher scores compared to those, who did not. education teachers from the research group demonstrated a statistically significant difference concerning sport branch, lesson infrastructure, training a school team, and doing regular exercise. It was determined that the physical education teachers, who dealt with team sport, had higher

social media teacher-student interaction levels compared to the teachers dealing with individual sports; the teachers, who were training school teams, had higher levels than those, who did not train a school team, and the teachers, who 
Table 5. Comparison of the social media teacher-student interaction levels of the physical education teachers from the research group concerning age and monthly income perception

\begin{tabular}{|c|c|c|c|c|c|c|c|c|}
\hline & & & $\mathbf{N}$ & $\bar{X}$ & Sd & $\chi^{2}$ & p & Difference \\
\hline \multirow{3}{*}{ Age } & (a) & 20-29 Years Old & 159 & 3.73 & .854 & \multirow{3}{*}{20.814} & \multirow{3}{*}{$.000^{*}$} & \multirow{3}{*}{$\begin{array}{c}\text { Yes } \\
(a)>(b) \\
(a)>(c)\end{array}$} \\
\hline & (b) & 30-39 Years Old & 159 & 3.14 & .590 & & & \\
\hline & (c) & 40 and Over & 72 & 2.90 & .621 & & & \\
\hline \multirow{3}{*}{$\begin{array}{l}\text { Monthly Income } \\
\text { Perception }\end{array}$} & $(x)$ & Low & 84 & 3.08 & .706 & \multirow{3}{*}{9.307} & \multirow{3}{*}{$.010^{*}$} & \multirow{3}{*}{$\begin{array}{c}\text { Yes } \\
(z)>(x) \\
(z)>(y)\end{array}$} \\
\hline & (y) & Medium & 261 & 3.32 & .751 & & & \\
\hline & (z) & High & 45 & 3.93 & .856 & & & \\
\hline${ }^{*} p<0.05$ & & & & & & & & \\
\hline
\end{tabular}

As is observed in Table 5, the social media teacher-student interaction levels of the physical education teachers from the research group demonstrated a statistically significant difference concerning age and monthly income perception. It was determined that the physical education teachers, who were 20-29 years old, had higher

\section{CONCLUSION \& DISCUSSION}

According to the results of this study, social media teacher-student interaction levels of the physical education teachers were determined at "medium level". Additionally, it was also determined that "virtual leader" characteristics of the physical education teachers shone out. It was determined that there was statistically significant difference in social media teacher-student interaction levels of the physical education teachers concerning school location, sport branch, physical education lesson infrastructure, training a school team, doing regular exercises, age, and monthly income perceptions; however, there was statistically no significant difference concerning gender, marital status, and the type of the school of the teachers.

Toğay et al. (29) stated that the education processes should be supported with social media; Ajjan and Hartshorne (1) suggested that social media well supports the information sharing necessary for active learning. Öztürk and Talas (25) emphasized that social media provides a more effective communication between the teachers and the students. McLoughlin and Lee (21) reported that social media networks can be considered as pedagogical tools; Albion (3) stressed the importance of use of new technologies in the context of education. Ferdig (12) suggested that social media support the pedagogical approaches such as active social media teacher-student interaction levels compared to the teachers between 30-39 and 40 and over; the teachers with higher monthly income perceptions had higher social media teacher-student interaction levels compared to those with low and medium perception levels.

learning, social learning, implementation, and learning communities. Bartlett-Bragg (6) mentioned that the new technologies including the social networks are quite appropriate domains for cooperative learning; Selwyn (28) asserted that social media is available for informal learning. Pettenati and Ranieri (26) stated that social networks ensure the formation of the application communities of online cooperative learning. Gray (13) mentioned that social media provides opportunities for learning. Considering the abovementioned views, that the social media teacher-student interaction levels of the physical education teachers were determined at "medium range" in this study, can be defined as a negative situation. It can be explained by the fact that the physical education teachers could not use effectively the internet-based social media networks emerged through the recent technological developments, or perhaps, it is because they are not sufficiently educated in this issue.

Avcı (5), Yetim and Göktaş (30), Çelikten et al. (8), Altıntaş (4), Eren Ökten and Karakuş (10), Katılmıs and Balc1 (16) stated that the teacher is the role model of the student. Since the "virtual leader" characteristics of the teachers came to the fore in this study, it can be considered as a pleasing result considering that there is sensitivity over displaying 
responsible behaviors in the social media, taking the lead and being an example.

In this research study, it can be considered as a surprising situation that the social media teacher-student interaction levels of the physical education teachers working in rural areas are higher compared to the ones working in urban areas. It can be said that there are more technological availabilities in urban areas; however, it can be explained by recent increase in the widespread use of mobile devices.

In this research study, it was determined that the social media teacher-student interaction levels of the physical education teachers training a school team are higher compared to the ones doing individual sport. It can be mentioned that team sports create more open settings for the socialization processes and thus, it can be considered that this situation is not surprising.

In the study, it was determined that the social media teacher-student interaction levels of the physical education teachers working at schools with sufficient infrastructure of physical education lessons are higher compared to the ones with insufficient infrastructure. Considering that the teachers with sufficient infrastructure of physical education lesson conduct more implementations in their lessons and in a more effective way, it can be suggested as an expected situation.

In this research study, it was determined that the social media teacher-student interaction levels of the physical education teachers training a school team are higher compared to the ones without a school team. It can be considered that the teachers training a school team enjoy the coaching experience and therefore, they are involved in a close communication with their students. Similar cases might be the motives behind this result.

\section{REFERENCES}

1. Ajjan $\mathrm{H}$, Hartshorne R. Investigating faculty decisions to adopt Web 2.0 technologies: Theory and empirical tests, Internet and Higher Education, 2008; (11): 71-80.

2. Alarcia O, Bravo I. The impact of ICTs on lecturer and students interaction in university education processes, Universities and Knowledge Society Journal, 2012; 9(2): 213228.

3. Albion PR. Web 2.0 in teacher education: two imperatives for action, Computers in the Schools, 2008; 25(3-4): 181-198.

4. Altıntaş ME. İlköğretim din kültürü ve ahlak bilgisi öğretmenlerinin gözüyle değer öğretimini gerçekleştiren öğretmenlerde olması gereken nitelikler (nitel bir araştırma), Sakarya Üniversitesi İlahiyat Fakültesi Dergisi, 2016; 18(34): 125-142.

Turk ل Sport Exe 2019; 21(1):129-135

(4) 2019 Faculty of Sport Sciences, Selcuk University
In this research study, it was determined that the social media teacher-student interaction levels of the physical education teachers doing regular exercises are higher compared to the ones without regular exercise. It can be mentioned that doing regular exercises contributes to the harmony with the social environment. Therefore, it can be suggested that this result is not anomalous.

In this research study, it was determined that the social media teacher-student interaction levels of the younger physical education teachers are higher compared to the older ones. It can be stated that young individuals use internet more compared to the old ones. This result can be attributed to this explanation.

In this study, it was determined that the social media teacher-student interaction levels of the physical education teachers with high perceptions about their monthly incomes are higher compared to the ones with low levels of perception. It can be suggested that the teachers believing in themselves to be richer will use internet more, and this result can be attributed to this explanation.

\section{RECOMMENDATIONS}

In order to improve the use of social media, conferences and seminars can be organized by the experts for the physical education teachers. Students can also attend educations about social media. The motives behind the shining "virtual leader" characteristics of the physical education teachers can be investigated through different studies. Similar research studies can be conducted with different research groups to contribute to the literature. It is considered useful that the social media teacherstudent interactions of the physical education teachers be investigated through qualitative research studies.

5. Avcı ÜP. Tasavvuf ve insan eğitimi, Türk Kültürü ve $\mathrm{Hac1}$ Bektaş Veli Araştırma Dergisi, 2003; (27): 1-9.

6. Bartlett-Bragg A. Reflections on pedagogy: Reframing practice to foster informal learning with social software, 2006. Available from: http://citeseerx.ist.psu.edu/viewdoc/download?doi=10.1.1.472 $.2265 \&$ rep $=$ rep1\&type $=$ pdf (Accessed January 17, 2019).

7. Çam E, Işman A. Teacher candidates' use of facebook for educational purposes, Procedia-Social and Behavioral Sciences, 2013; (106): 2500-2506.

8. Çelikten M, Şanal M, Yeni Y. Öğretmenlik mesleği ve özellikleri, Erciyes Üniversitesi Sosyal Bilimler Enstitüsü Dergisi, 2005; (19): 207-237.

9. Dron J, Anderson T. Teaching Crowds: Learning and Social Media. Canada: Athabasca University Press, 2014. 
10. Eren Ökten C, Karakuş N. Türkçe öğretmeni adaylarının örgütsel öğrenme farkındalığının geliştirilmesi, Erzincan Üniversitesi Eğitim Fakültesi Dergisi, 2017; 19(3): 1-15.

11. Evans D. Social Media Marketing: An Hour A Day. Indianapolis: Wiley Publishing. 2008.

12. Ferdig R. Examining social software in teacher education, Journal of Technology and Teacher Education, 2007; (15): 510.

13. Gray B. Informal learning in an online community of practice, Journal of Distance Education, 2004; (19): 20-35.

14. Gülseçen S, Gürsul F, Bayrakdar B, Çilengir S. Canım S. Yeni Nesil Mobil Öğrenme Aracı: Podcast, Akademik Bilişim Konferans1, Muğla, 2010: 787-792.

15. Karasar N. Bilimsel Araştırma Yöntemi, Nobel Yayın Dağıtım, Ankara, 2008: 68.

16. Katılmış A, Balcı A. Coğrafya öğretmeni adaylarının değerler eğitimine yönelik görüşlerinin incelenmesi, Marmara Coğrafya Dergisi, 2017; (35): 1-12.

17. Khan S. Impact of social networking websites on students, Abasyn Journal of Social Sciences, 2012; 5(2): 56-77.

18. Kirtiş KA, Karahan F. To be or not to be in social media arena as the most cost-efficient marketing strategy after the global recession, Procedia Social and Behavioral Sciences, 2011; 24(1): 24.

19. Korucu AT, Usta E. Sosyal medya öğretmen-öğrenci etkileşimi ölçeği: geçerlik ve güvenirlik çalışması, İlköğretim Online, 2017; 16(1): 197-216.

20. Küçükali M. Üniversite öğrencilerinin sosyal medya kullanımı: Atatürk Üniversitesi örneği, Bartın Üniversitesi İktisadi İdari Bilimler Fakültesi Dergisi, 2016; 7(13): 531-546.

21. McLoughlin C, Lee MJW. Social Software and Participatory Learning: Pedagogical Choices with Technology Affordances in the Web 2.0 Era, Singapore: Faculty of Education and Arts Publications, 2008.

22. Miller D, Costa E, Haynes N, McDonald T, Nicolescu R, Sinanan J, Spyer J, Venkatraman S, Wang X. How the World Changed Social Media, London: UCL Press, 2016.

23. Morkoç DK, Erdönmez C. Web 2.0 uygulamalarının eğitim süreçlerine etkisi: Çanakkale sosyal bilimler meslek yüksekokul örneği, Online Academic Journal of Information Technology, 2014; 5(15): 25-48.

24. Munoz CL, Towner, TL. Opening Facebook: How to Use Facebook in the College Classroom. Proceedings of Society for Information Technology and Teacher Education International Conference, Virginia, 2009: 2623-2627.

25. Öztürk MF, Talas M. Sosyal medya ve eğitim etkileşimi, Zeitschrift für die Welt der Türken/Journal of World of Turks, 2015; 7(1): 101-120.

26. Pettenati MC, Ranieri M. Informal Learning Theories and Tools to Support Knowledge Management in Distributed CoPs, Innovative Approaches for Learning and Knowledge Sharing, 2006: 345-355.

27. Roy DR, Chakraborty SK. Impact of social media/social networks on education and life of undergraduate level students of Karimganj town-a survey, International Research Journal of Interdisciplinary \& Multidisciplinary Studies, 2015: 1(1), 141- 147

28. Selwyn, N. Web 2.0 Applications as Alternative Environments for Informal Learning-A Critical Review, in Paper for Ceri-Keris International Expert Meeting on ICT and Educational Performance, 2007; (16): 17.

29. Toğay A, Akdur TE, Yetişken İC, Bilici A. Eğitim Süreçlerinde Sosyal Ağların Kullanımı: Bir MYO Deneyimi, XIV. Akademik Bilişim Konferansı, 2013: 28-30.

30. Yetim AA, Göktaş Z. Öğretmenin mesleki ve kişisel nitelikleri, Kastamonu Eğitim Dergisi, 2004; 12(2): 541-550. 